\title{
Impaired Insulin and IGF-2 signalling in the primordial growth disorder 3-M Syndrome
}

\author{
Jins Kallampallil, Ksenija Acimovic, Daniel Hanson, Andrew Whatmore, Peter Clayton
}

Paediatric Endocrinology, Centre for Paediatrics and Child Health, Institute of Human Development, Faculty of Medical and Human Sciences, The University of Manchester

\section{Introduction}

- 3-M Syndrome is a rare autosomal recessive primordial growth disorder associated with a distinct facial appearance, prominent fleshy heels and minor skeletal abnormalities ${ }^{1}$ (Fig. 1).

- Caused by mutations in CUL7, OBSL1 and CCDC8,3

- In cells derived from patients with 3-M syndrome, Growth hormone and IGF-1 signalling and expression of IGF-2 and insulin receptor isoforms are all altered ${ }^{3-5}$.

In view of this altered growth factor signalling, we have investigated the activation of AKT by IGF-2 and Insulin.
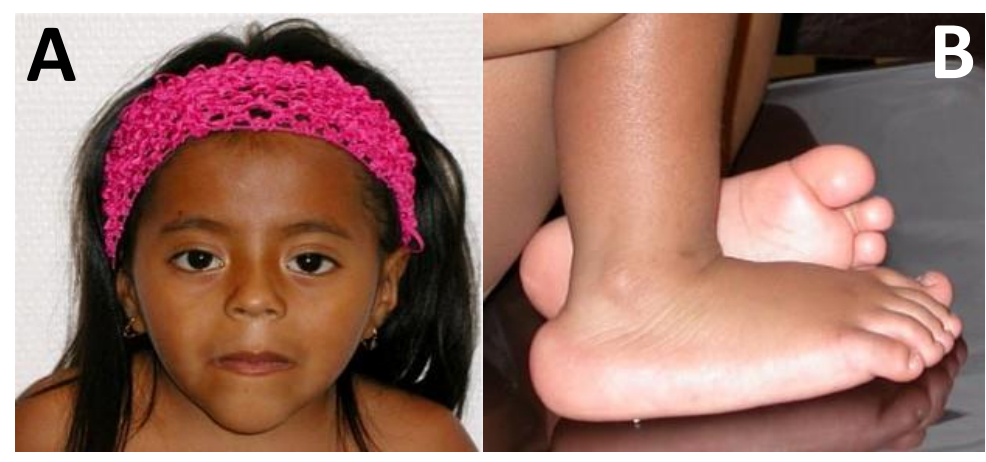

Fig. 1 - Phenotypic features of 3-M syndrome

A) Fleshy tipped nose, prominent full lips, triangular shaped face and prominent forehead. B) Prominent fleshy heels (Images courtesy of Professor Peter Scambler, UCL Institute of Child Health, London)

\section{Method}

- Fibroblasts were cultured from skin biopsies taken from 3 3-M patients (1 each with a CUL7, OBSL1 or CCDC8 mutation) and from normal controls.

- Sub-confluent cells were stimulated with $500 \mathrm{ng} / \mathrm{ml}$ IGF-2 or $100 \mathrm{ng} / \mathrm{ml}$ insulin for $0,5,15$ and 60 minutes.

- Relative phosphorylation of AKT was assessed by western blotting and comparisons made both within and between cell lines.

\section{Conclusion}

- Reduced AKT activation in response to IGF-2 and insulin stimulation mirrors that previously seen with IGF-1 although to a lesser extent .

- $C C D C 8^{-/}$cells were least affected, consistent with the clinical phenotype observed in these children.

- Diminished growth factor signalling could account for the growth failure in 3-M Syndrome, and may contribute to insulin resistance observed in children born small for gestational age.

\section{Results}

- Relative pAKT was reduced in 3-M fibroblasts compared to normal cells when stimulated with either insulin $(p=0.048)$ or IGF-2 ( $p=0.033$ ) (Fig. 2).

- For both treatments, CUL7\% and OBSL $1^{\%}$ cells had a markedly lower activation of pAKT than did $C C D C 8^{-/}$cells.

- $C U L 7^{-1-}$ cells had an earlier activation in response to insulin ( $p=$ 0.016) than other cell types.

- After 60 mins Insulin stimulation, pAKT was $65-70 \%$ of normal in CUL $7^{-1-}$ and OBSL $1^{-1-}$ and $90 \%$ in CCDC $8^{-1}$

- With IGF-2, pAKT at 60 mins was $70-80 \%$ of normal in all 3-M cells.

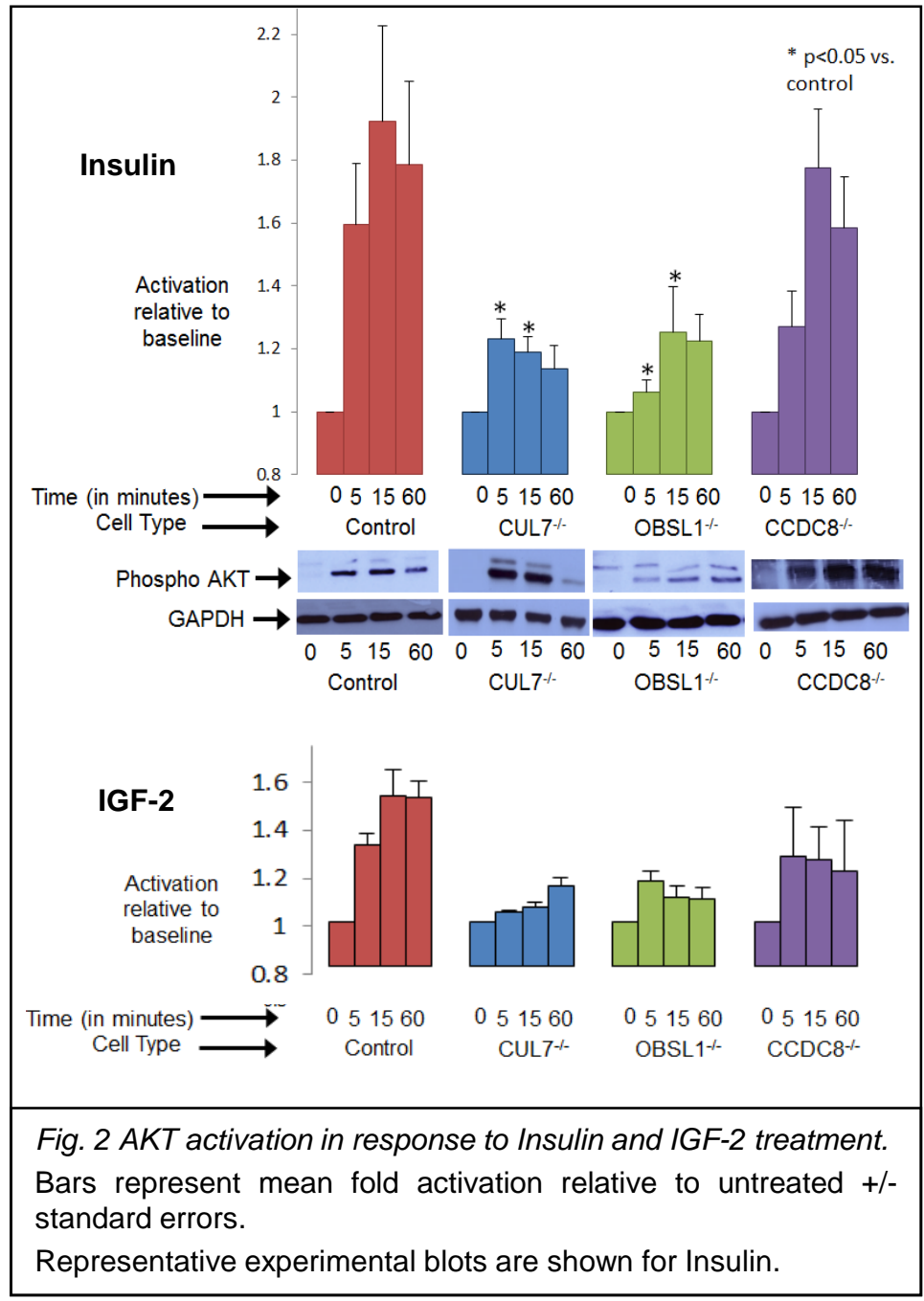

\section{References}

1) MILLER, J. D. et al. 1975. Birth Defects Orig Artic Ser, 11, 39-47

2) CLAYTON, P.E. et al. 2012. Clin Endocrinol 77, 335-42

3) HANSON, D., et al. 2012. J Mol Endocrinol. 49, 267-275

4) HANSON, D., et al. 2014. J Mol Endocrinol. 52(3), 333-44

5) MURRAY P.G., et al. 2013. Endocrine Connections. 2(4), 225-35 